\title{
Edaphic attributes and loss of soil and nutrients according to the management systems for horticultural crops
}

\author{
José Mário Piratello Freitas de Souza', Lúcia Helena Cunha dos Anjos², \\ Marcos Gervasio Pereira²*, Roni Fernandes Guareschi², João Henrique Gaia-Gomes²
}

'National Institute for Colonization and Agrarian Reform, Rio de Janeiro, RJ, Brazil,

${ }^{2}$ Federal Rural University of Rio de Janeiro, Seropédica, RJ, Brazil

corresponding author, e-mail: mgervasiopereira01@gmail.com

\begin{abstract}
The effects of conventional tillage (CT), level cultivation (LC), minimum cultivation (MC) and a plot without a cover crop (WC) in the contents of soil nutrients ( $P, K, C$ a and $\mathrm{Mg}$ ), total organic carbon (TOC), bulk density $(B d)$, soil water infiltration rate $(B I R)$ and losses of TOC and nutrients $(P$ and $\mathrm{K}$ ) by erosion were evaluated in areas with the cultivation of horticultural crops. Wischmeier plots were installed in an Oxisol with $30 \%$ of slope. Soil samples were collected at 0.0-0.05 and 0.05-0.10 m depths to physical and chemical characterization. The WC plot reduces soil SWIR values and lead to a higher losses soil, TOC and macronutrients ( $\mathrm{Ca}, \mathrm{P}, \mathrm{Mg}$ and $\mathrm{K}$ ). The CT resulted in higher losses of soil, TOC, P and K by erosion, contributing to reduce the TOC, P, Ca, Mg and SWIR of the soil. The MC was the most indicated management, since it helps to reduce losses of soil, TOC, P and K by erosion, and increase the TOC, BIR, P, K, Ca and Mg of the soil. The LC when compared to the CT reduces the losses of soil TOC, P and K by erosion, and increase the BIR values.
\end{abstract}

Keywords: Hydric erosion, minimum tillage, oxisol, strong wavy relief

\section{Introduction}

The vegetable production is the main economic activity of the municipality of Paty do Alferes, Rio de Janeiro, Brazil (Pinheiro et al., 2004; Santos et al., 2002; Fontes et al., 2013). The region has characteristics that favor erosion, such as a sloping relief (20 to $45 \%$ slope) and a rainy period of seven to eight months (October to May) (Santos et al., 2002). In addition, the vegetables cultivation is mainly carried out in areas with uneven terrain and inadequate soil preparation, favoring the risks of soil and nutrient losses by erosion (Santos et al. 2002; Fontes et al., 2013).

This type of soil preparation for vegetables cultivation provides a reduction in soil organic matter contents (Pinheiro et al., 2003; Pinheiro et al., 2004; Fontes et al., 2013), increase Bd (Fontes et al. 2013), reduced total porosity (Fontes et al., 2013), increased soil losses due to erosion (Núñez et al., 2006 b; Fontes et al., 2013) and reduced fertility when compared to systems of conservation (Santos et al., 2002), resulting in reductions in the crop yield (Pereira \& Rodrigues, 2013).

In this context, the adoption of conservation management practices that favor the continuous contribution of organic matter to the soil, are of fundamental importance in the recovery of physically degraded soils (Portela et al, 2010). These results can be verified through the 
studies published by Santos et al. (2002), Pinheiro et al. (2004), Nunez et al., (2006 a, b), Fontes et al. (2007) and Pereira \& Rodrigues (2013), who evaluated the chemical and physicalhydric attributes of an Oxisol in the municipality of Paty do Alferes (RJ), Brazil, under different management systems for vegetables cultivation, observed that the minimum cultivation (MC) was the most recommended for the area conditions. The higher content of SOM as a function of $\mathrm{MC}$ increases the cation exchange capacity (CEC), retains more nutrients in the system and improves the availability of these nutrients, with reduction of $\mathrm{P}$ adsorption and cation leaching (Trevisan et al., 2008; Valadares et al. al., 2012).

The aim of this study was to evaluate the influence of systems of cultivation - conventional tillage (CT), level cultivation (LC), minimum cultivation (CM) and one plot without cover crop (WC) - on the soil nutrient content ( $P, K, C$ a and $\mathrm{Mg}$ ), total organic carbon (TOC), bulk density $(\mathrm{Bd})$, soil water infiltration rate(SWIR) and losses of soil, TOC and nutrients ( $P$ and $K$ ) by erosion in horticultural crops areas in the municipality of
Paty do Alferes, RJ, Brazil.

\section{Material and Methods}

The experimental plots where the study was carried out were installed in 1995, in the experimental field of the Rio de Janeiro State Agricultural Research Company (Pesagro), in Paty do Alferes, in the Caetés watershed. In the studied area, the strong corrugated relief predominates. The climate is a CW type, according to the Köppen's classification, where average annual precipitations of 1,200 $\mathrm{mm}$ are observed, with predominance of rain from November to January, corresponding to approximately $50 \%$ of the annual precipitation.

The experimental plots were arranged in a hill with a linear slope and convex contour with $30 \%$ of slope. Plots were carried out in dimensions of $22.0 \times 4.0 \mathrm{~m}$ (area of $88 \mathrm{~m}^{2}$ ), with a water and sediment collection point at the end of each plot, according to the Wischmeier model. The soil was classified as a typical Oxisol (Santos et al., 2013) and some chemical and physical attributes (Donagema et al., 2011) of this soil are presented in Table 1.

Table 1. Chemical and physical attributes of the soil horizons in the studied area.

\begin{tabular}{|c|c|c|c|c|c|c|c|c|c|c|c|}
\hline & Depth & $\mathrm{pH}$ & $\mathrm{Al}^{+3}$ & $\mathrm{H}^{+}$ & $S$ & $T$ & $\mathrm{~V}$ & GF & Sand & Silt & Clay \\
\hline Horizon & $\mathrm{m}$ & $\mathrm{H}_{2} \mathrm{O}$ & \multicolumn{4}{|c|}{$---\mathrm{cmol}_{\mathrm{C}} \mathrm{kg}^{-1}-\mathrm{C}^{--}$} & \multicolumn{2}{|c|}{$--\%$-- } & - & $\mathrm{kg}$ & - \\
\hline Ap & $0.0-0.22$ & 5.8 & 0,0 & 5.9 & 2.8 & 8.7 & 32 & 16 & 510 & 110 & 380 \\
\hline Bw2 & $0.68-0.92$ & 4.8 & 0.5 & 2.6 & 0.9 & 3.1 & 29 & 100 & 400 & 150 & 450 \\
\hline
\end{tabular}

${ }^{*} \mathrm{GF}=$ Degree of Flocculation; $\mathrm{S}=\mathrm{S}$ value (sum of $\mathrm{Ca}+\mathrm{Mg}+\mathrm{K}+\mathrm{Na}$ ); $\mathrm{T}=\mathrm{T}$ Value (sum of $\left.\mathrm{S}+\mathrm{Al}+\mathrm{H}\right) ; \mathrm{V}=$ base saturation.

The cover vegetation of the experimental area before the plots installation consisted of unmanaged pasture with Melinis minutiflora. As previously mentioned, in 1995, nine Wischmeier plots (with water and sediment collectors) were installed, where different soil preparation systems are being used to study the cycle of different horticultural crops. In these plots, the crops of okra, cauliflower, tomato, bean, pepper and zucchini are alternated, depending on the climatic conditions. Crops received the same fertilization and phytosanitary control, despite the soil preparation system.

The following treatments of soil preparation and agricultural cultivation were started at the end of the year 1995 and repeated continuously until 2002) Conventional tillage (CT) - planting that uses burned residues from the previous crop, plowing with discs in the depth of about $20 \mathrm{~cm}$ and a harrowing with tractor in the direction of the higher slope (down hill); 2) Preparation for the level cultivation (LC) planting without burning the previous crop residues, plowing with animal traction using a moldboard plow in the direction of the contour lines, with containment strips on every $7 \mathrm{~m}$ (grass) ; 3) minimal cultivation (MC) - direct cultivation, without burning of residues from the previous crop and with preservation of the vegetal cover in the lines of the crop; 4) reference plot, without a cover crop (WC) - only a plowing and harrowing with a tractor in the direction of the highest slope (down hill), with surface weeding or herbicides application. Three replicates were set for each treatment.

Soil samples were collected from May 2000 to November 2001, at different times, within the areas with different soil management. The 
sampling times and treatments are identified as follows: $05 / 15 / 2000$, pod beans; $11 / 13 / 2000$, fallow; 04/26/2001 sweet pepper; 06/07/2001, fallow; $11 / 29 / 2001$, pod beans. The samples were collected at depths of 0.0-0.05 and 0.05-0.10 m, with the aid a soil auger, in the planting line of the crop, for each plot. Three composite samples were collected from ten simple samples. Afterwards, the samples were air-dried, homogenized and passed through a $2.0 \mathrm{~mm}$ mesh sieve (air dried soil) for subsequent chemical fertility analyzes (Donagema et al., 2011).

At depths of $0.0-0.05$ and $0.05-0.10$ $\mathrm{m}$, undisturbed samples were also collected in the different areas, with a volumetric ring (Donagema et al., 2011) for the determination of soil density (Ds).

The water infiltration in the soil was determined by the concentric double cylinder method, after wetting the soil until reaching constant values (Embrapa, 1997). Due to the slope degree of the evaluated plots, a thin layer of soil was removed in the highest portion of the soil, in the exact place where the rings were installed, resulting in homogeneous distribution of the height of the water slide inside the rings.
Measurements of soil and water loss were obtained in the period 2000-2001, according to the occurrence of rainy events (Figure 1) and the resulting run off water. The eroded material was deposited in the collection box of each plot, which has two boxes, where the first box has a holding capacity of 500 liters and the second box with a capacity of 1000 liters. Between the two boxes there is a screen with 12 subdivisions to exit the drained water. The eroded material disposed in the carton was homogenized and 1 liter was used, discarding the remained after noting the total amount. If the box presented a collection of less than 1 liter, the entire contents were removed. In sub-samples of suspension and sediment, from each plot, aliquots were taken to quantify the nutrient content ( $P$ and $\mathrm{K}$ ) and TOC, according to the Embrapa (1977).

The experiment was carried out in a randomized block design, in a $4 \times 3 \times 2$ factorial scheme, with 4 treatments, 3 repetitions and 2 depths $(4 \times 3 \times 2)$. Subsequently, the results were submitted to variance analysis with the application of the $\mathrm{F}$ test and the mean values were compared by the Tukey's test at $5 \%$ of probability, with the aid of the software Statistica.

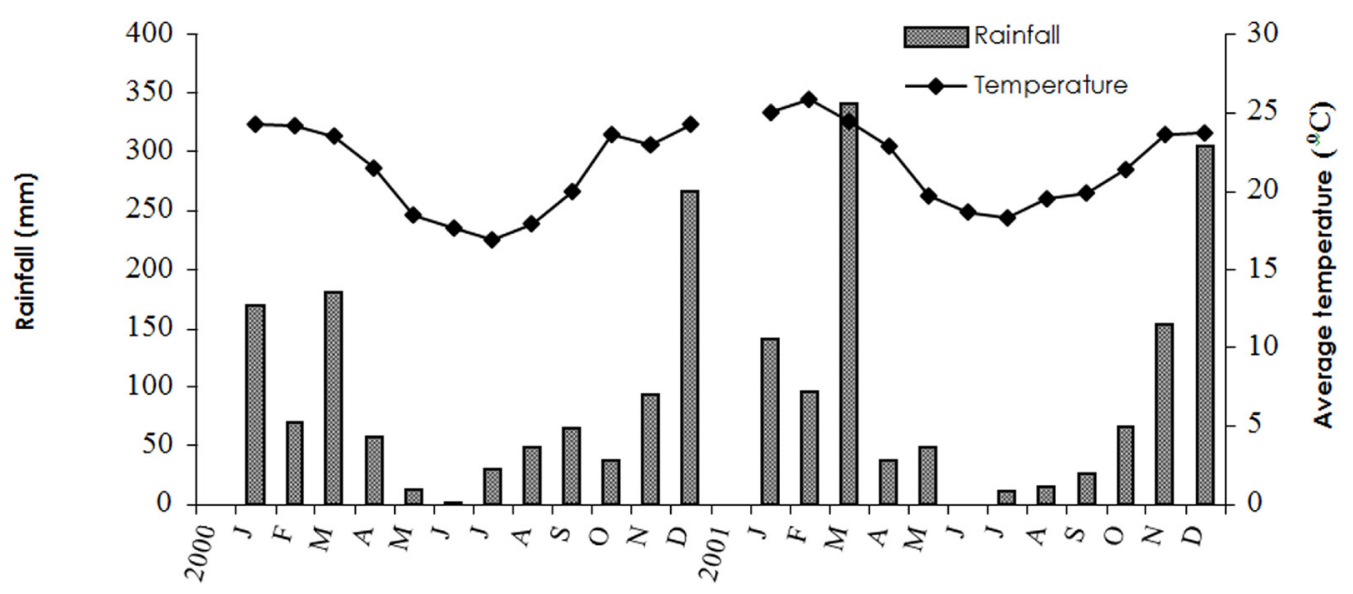

Period year/mouth

Figure 1. Rainfall and temperature distribution from January 2000 to December 2001 (Source: Pesagro-Rio, Avelar Station).

The principal components analysis (PCA) was also carried out using the Assistat software for the attributes BIR (basic infiltration rate of water in the soil); TOC (total organic carbon content of soil); SL 2000 (soil loss in the year 2000), SL 2001 (soil loss in the year 2001); KLW (loss of K by runoff water); PLW (loss of P by runoff water); LPS (loss of
$P$ in sediments); LKS (loss of $\mathrm{K}$ in sediments); LTOCS (loss of TOC in sediments); TPS (soil P content); TCaS (Ca content in soil); TMgs (Mg content in soil) and TKS (soil K content) in cultivated areas (CT, LC and MC); The ACP is used to reduce data dimensions and to favor the analysis using the graph of the circle of correlations. 


\section{Results and Discussion}

No differences were observed in the total organic carbon content (TOC) between the depths in the different evaluated soil managements systems (Figure 1a). Also in Figure la, it can be observed that, regardless the depth, the reference area, without vegetation cover (WC) presented lower TOC contents when compared to the other treatments. This is due to the low $C$ in the soil, caused by the absence of a constant cover vegetation. In addition, soil disturbance and the lack of cover vegetation of this treatment, besides contributing to soil degradation, resulting in a soil exposed to the direct incidence of solar radiation and rainfall, resulting in a favorable environment for the mineralization of the soil organic matter and higher soil and sediments containing carbon losses by erosion (Figure 1b, c). According to Panachuki et al. (2011), this pattern is observed due to the absence of soil cover, resulting in a low value of roughness of the soil surface with consequent sealing of the surface promoted by the impact of the raindrops, which favor the increase of the surface runoff. Similar results were observed by Pinheiro et al. (2003) and Amaral Sobrinho \& Mazur (2005) when assessing different management systems in vegetable crops, also observing lower TOC levels and higher soil losses in the reference area (soil without cover) in relation to conventional tillage systems (CT), level cultivation (LC) and minimum cultivation (MC).

It is also verified that among the cultivation systems, in the MC, higher TOC contents were observed when compared to the CT (0.0-0.10 m) while the LC area presented intermediate values (Figure 1a). It can be inferred that the lower TOC contents of the CT when comparing to MC occur due to its higher soil mobilization (plowing and harrowing) that leaves the soil more exposed to the solar radiation and rain, being possible to incorporate the vegetal residues to the soil, accelerating its decomposition. Another aspect to be considered is that the soil mobilization defragments the aggregates, exposing the protected SOM, favoring their decomposition and consequently decreasing the soil stock values (Guareschi et al., 2012). Additionally, it should be considered that the lack of vegetation cover and the degradation of the aggregates caused by soil mobilization increases losses of soil (Figure 1b) and sediment and organic carbon (Leite et al., 2009; Fontes et al., 2013) (Figure 1c). In an antagonistic way, in the CM area, due to its smaller mobilization, there is a higher entrance of organic material in the soil surface, which contributes to a higher maintenance of the aggregates, favoring the internal flow of water and reducing the losses of $\mathrm{C}$ by mineralization and / or removal, along with the mineral particles by erosion (Amaral Sobrinho \& Mazur, 2005, Nuñez et al., 2006b) (Figure 1 a, b, )

Lower soil and sediment losses with TOC were observed in the MC area in comparison to the other treatments. This pattern may be related to the higher soil cover, which has the capacity to cushion the impact of the kinetic energy of the raindrops and to ease the runoff (Bezerra \& Cantalice, 2006; Bertol et al., 2007; Leite et al., 2009; Panachuki et al., 2011; Tartari et al., 2012; Fontes et al., 2013).

The intermediate results of TOC, soil losses and TOC losses in the eroded LC sediment (Figure $1 \mathrm{a}, \mathrm{b}, \mathrm{c}$ ) between the $\mathrm{CT}$ and $\mathrm{MC}$ systems demonstrated that the adoption of erosion control practices, such as contour lines and containment with grasses planting, may be hindering the runoff, reducing sediment transport capacity by erosion and preserving $C$ contents in the area. Similarly, Pinheiro et al. (2003) and Amaral Sobrinho \& Mazur (2005) also showed that the LC areas present intermediate values of TOC and soil losses when compared to the areas CT and MC. It is also observed lower soil losses in LC when compared to CT in 18\% in 2000 and $32 \%$ in 2001 . According to Leite et al. (2009), this reduction is due to the fact that the level preparation provides a reduction in the velocity and shear stress of the surface runoff, reducing its transport capacity and the soil particles detachment. This demonstrates the importance of erosion control techniques, and that the adopted CT as the main soil management in the Paty dos Alferes (RJ) region should be avoided, aiming at better soil preservation.

Regarding the values of $\mathrm{Bd}$, no significant differences between treatments were observed. The mean values obtained were $1.18 ; 1.31 ; 1.21$; 
a)

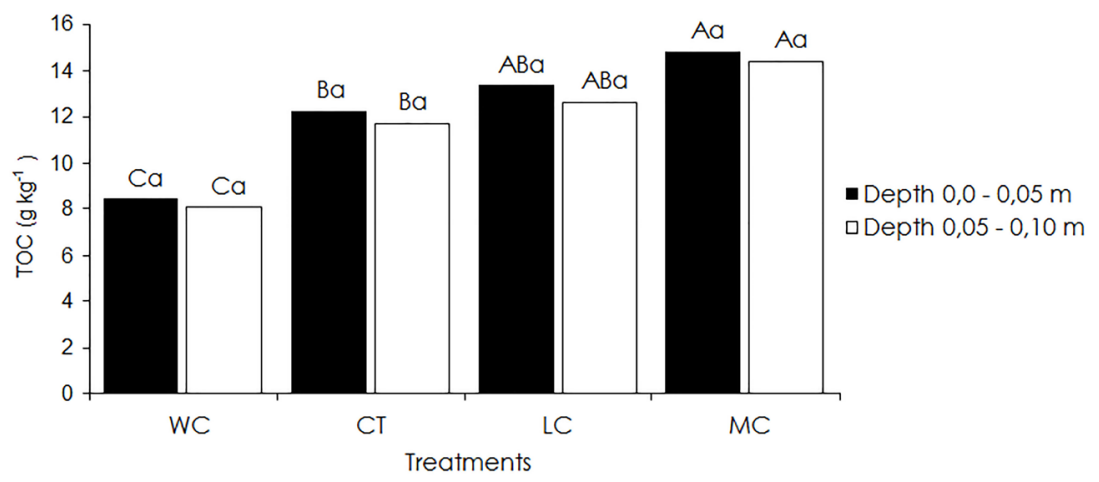

b)

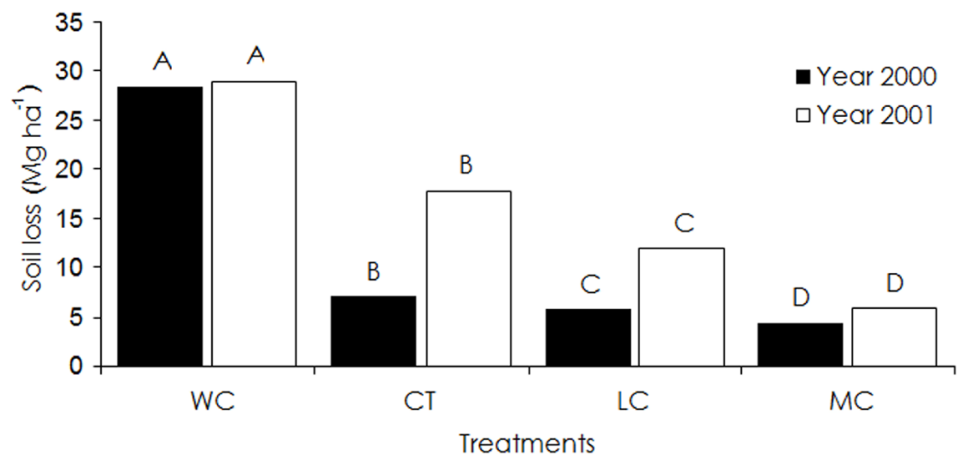

c)

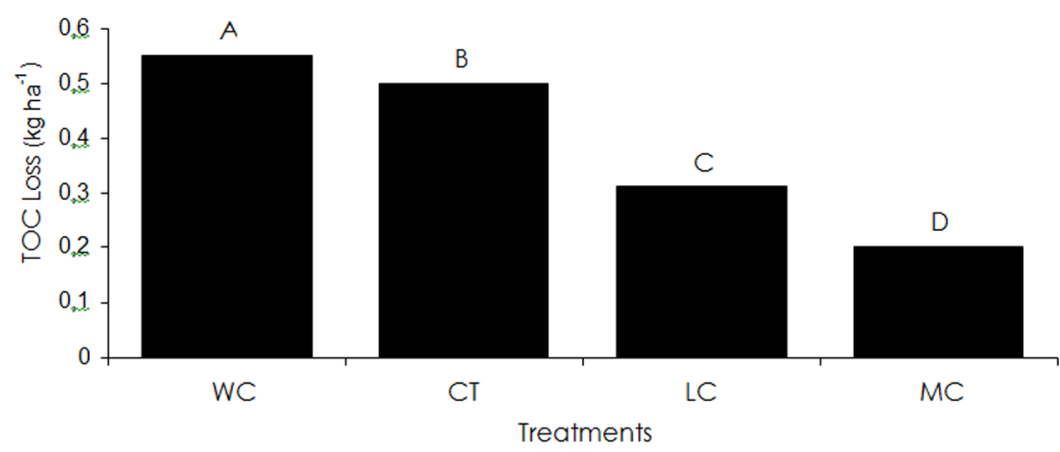

Figure 1. Total organic carbon (TOC) contents (a), soil loss (b) and total TOC loss (c) in the eroded sediment for each studied treatment.

$1.20 \mathrm{Mg} \mathrm{m}^{3}$ for MC, LC, CT and WC, in the 0.0$0.05 \mathrm{~m}$ layer; And 1.23; $1.27 ; 1.23 ; 1.20 \mathrm{Mg} \mathrm{m}^{3}$ for MC, LC, CT and WC in the layer of 0.05-0.10 $\mathrm{m}$, respectively. This result can be attributed to the short time of the experiment, meaning that the six years of the experiment installation were not enough to promote variations in the soil physical attributes. However, Fontes et al. (2013), when evaluating the same areas of this study in 2009/2010, found that the presence of cover vegetation and the higher TOC content of $\mathrm{MC}$ reduced the $\mathrm{Bd}$, when compared to $\mathrm{WC}$ and $\mathrm{CT}$, in the soil surface. These authors also mentioned that the highest values of $\mathrm{Bd}$ in the area of $\mathrm{WC}$ and $\mathrm{CT}$ in relation to $\mathrm{MC}$ are related to the absence of cover vegetation and lower aggregation, which can lead to compaction and sealing of the soil surface.

This pattern is confirmed by the analysis of the basic infiltration rate (BIR) among treatments (Figure 2), where the systems with the highest soil exposure to the climatic conditions (WC, CT 
and LC) presented lower values of this attribute when compared to MC. This fact demonstrates the importance of maintaining soil cover and minimum soil cultivation to preserve the physical attributes and prevent the formation of surface sealing, which is one of the main causes of the decrease of soil water infiltration (Panachuki et al., 2011). According to this idea it is possible to observe that areas with lower BIR resulted in higher soil losses (Figure 1 b).

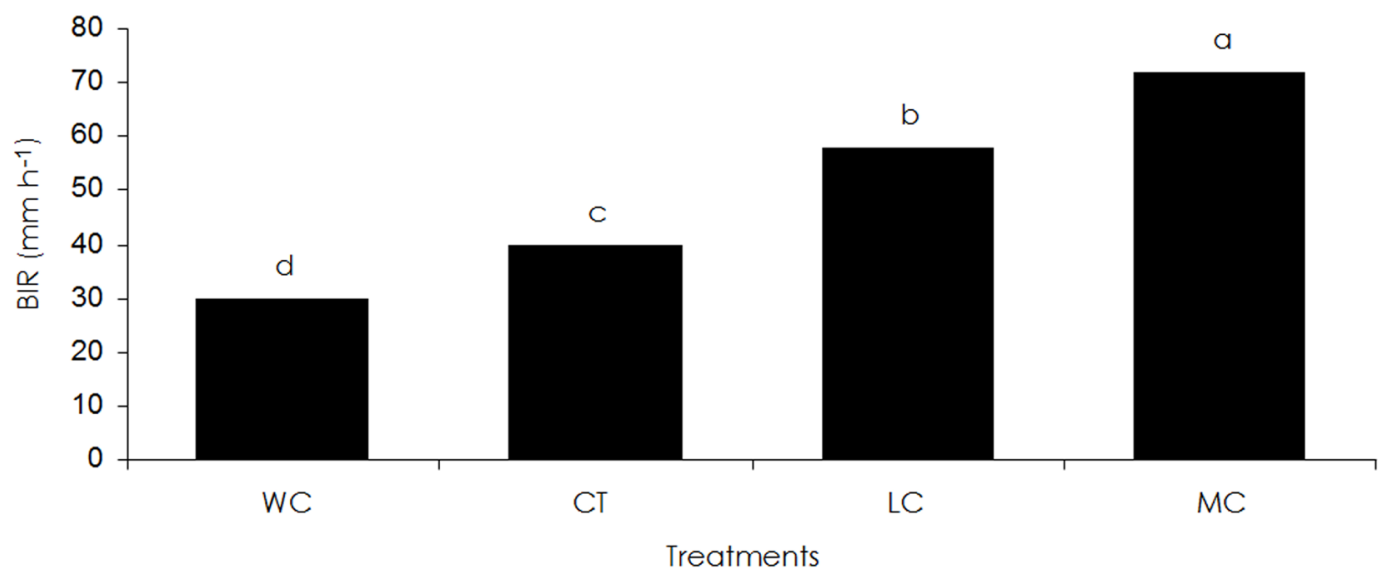

Figure 2. Mean values of the basic infiltration rate (BIR) of water as a function of soil preparation treatments. WC without cover, CT - conventional tillage, LC - level cultivation, MC - minimum cultivation.

Similar results to the observed in this study demonstrate that preparation systems that minimize the soil stirring and increase TOC, as MC increase BIT and decrease the erosion process (Leite et al., 2009; Cunha et al., 2011; Panachuki et al. , 2011). In MC, the residues on the soil surface provide a soil cover, which has a direct and effective action in the reduction of water of erosion, due to the dissipation of kinetic energy of the rain drops, reducing the destruction of the aggregates and individualization of soil particles and surface sealing and increasing soil water infiltration (Leite et al., 2009).

It can also be inferred that the higher TOC contents of $M C$ in comparison to the other treatments are contributing to an improvement in aggregation, with consequent increase of porosity and BIR. It is known that in tropical soils, MOS acts strongly in the formation of larger aggregates, because in addition to its aggregator function, it slows the entry of water in the aggregates, increasing their resistance when moistened. This pattern is evidenced in the study of Fontes et al. (2013) where the authors found in the same area of study that MC presented higher pore connectivity and more homogeneous poral quantification than in CT and WC. These authors also reported that this pattern demonstrates the importance of maintaining soil aggregation through a conservationist management.

It is also verified in the present study that the runoff water carried soluble and adsorbed phosphorus and potassium (Figure 3a, b). MC stands out in comparison to the other treatments as the soil preparation system that presented lower losses of $\mathrm{P}_{2} \mathrm{O}_{5}$ and $\mathrm{K}_{2} \mathrm{O}$ in sediments and water from the runoff (Figure $3 a, b)$. This result can be attributed to the lower losses of soil and TOC (Figure 1b, c) of this system when compared to others and also to its higher TOC contents, which increase the cation exchange capacity of the soil, retaining these nutrients in the mineral colloids with higher intensity. Similar results were observed by Amaral Sobrinho \& Mazur (2005) and Leite et al. (2009) who also found that CM reduced losses of $\mathrm{P}$ and $\mathrm{K}$ when compared to CT and LC. Likewise, Thomazini et al. (2012) also verified higher losses of $\mathrm{K}$ in the sediments of crops that do not promote soil cover, with higher losses of this nutrient in the cultivated area.

In the same way as observed for soil losses, LC stands out as the second tillage system with lower $\mathrm{P}$ and $\mathrm{K}$ losses in the sediments and $\mathrm{K}$ in the water from the runoff (Figure $3 a, b$ ). It can also be inferred that this result is due to its lower soil loss due to the erosion verified in this treatment, promoted by the increase of the surface roughness due to the furrows left by the sowing machine or by 
the cultivation, forming obstacles to the surface runoff, reducing the speed and consequently the transport capacity of sediments and nutrients. It was also due to the use of natural barriers, which are efficient agricultural practices to promote soil conservation and fertility maintenance (Nuñez et al., 2006b; Leite et al., 2009).

a)

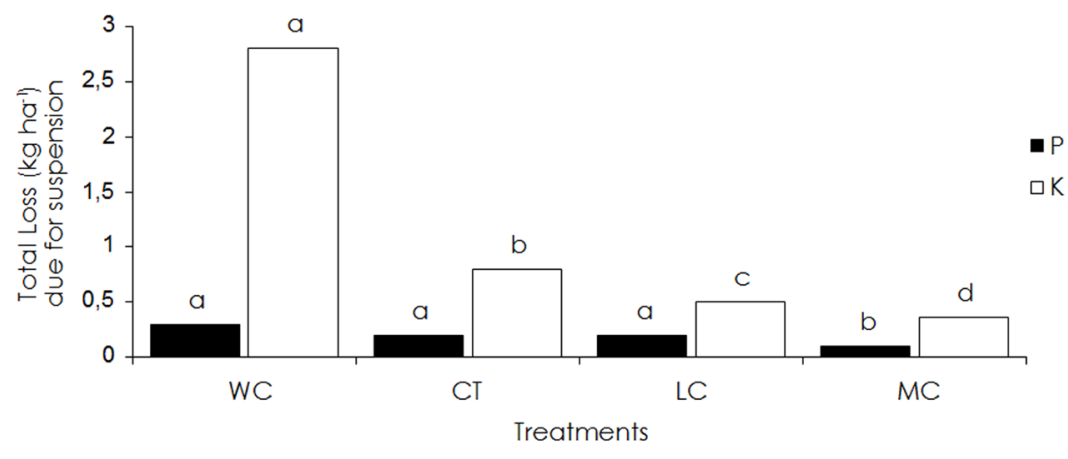

b)

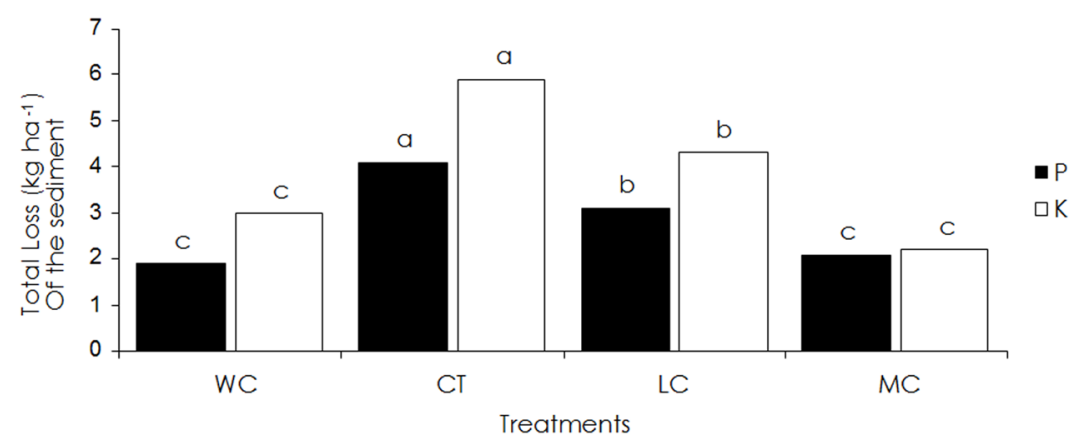

Figure 3. Total loss of $P$ and $K$ from runoff water (suspension sediments + diluted elements) - (a), and from sediments (b), for the different evaluated treatments. WC - without cover, CT - conventional tillage, LC level cultivation, MC - minimum cultivation

In the CT area, it is observed that the burning of residues from the previous crop, and plowing and harrowing with a tractor in the direction of higher slope, lead to higher losses of soil and nutrients, such as $P$ and $K$ in runoff water and sediments (Figure $3 a, b$ ). It is observed that this treatment lost more nutrients when compared to $M C$, with about $56 \%$ of $K$ in the water from the runoff and $49 \%$ and $63 \%$ of $P$ and $K$, respectively, in the sediments. When compared to the LC, the CT lost more than $37 \%$ of $K$ in the runoff water and $24 \%$ and $27 \%$ of $P$ and $K$, respectively, in the sediments. In the present study, as observed by other authors (Nuñez et al., 2006; Leite et al., 2009), is can be inferred that this type of soil preparation can cause financial losses to the growers of the area, and high environmental impact.

Lower losses of $\mathrm{P}$ and $\mathrm{K}$ in the sediments of the WC area compared to the CT and LC (Figure 3 b) can be attributed to the lack of fertilization of the WC area. Even with higher soil losses, due to the low levels of these nutrients in the soil, lower $P$ and $\mathrm{K}$ were adsorbed to the sediments.

It was verified that losses of soil, TOC and nutrients ( $P$ and $K$ ) influenced soil $P, C a, M g$ and $\mathrm{K}$ contents, leading to differences between the evaluated treatments (Table 2). Among the depths, there were only differences in $\mathrm{K}$ contents between the cultivated systems (CT, LC and MC), where in the 0.0-0.05 $\mathrm{m}$ layer were observed higher values than in the 0.05-0.10 layer (Table 2). This pattern can be due to the mineralization of 
the vegetal residues on the soil surface, providing more potassium in this layer. This nutrient occurs free in the vegetal tissues and can be easily removed by water after senescence (Garcia et al., 2008).

In both evaluated depths, the WC area resulted in lower values of $\mathrm{P}, \mathrm{Ca}, \mathrm{Mg}$ and $K$ compared to other treatments (Table 2). This result is due to the fact that this area does not receive fertilization, being submitted to higher and constant losses of soil and TOC when compared to the other treatments, which carry with them the studied nutrients.

Regardless the analyzed depth, the areas with $M C$ and $L C$ presented similar levels of $P, C a$ and Mg higher levels than CT (Table 2). This result may be due to the lower losses of soil, TOC and nutrients $(\mathrm{P})$ of $M C$ and $L C$, when compared to CT. Due to the time of adoption of these systems, it is observed the increase of cations (Ca, Mg) and anions $(P)$ in the areas of $M C$ and LC. In addition, the higher TOC contents may contribute to the release of soluble organic compounds capable of competing for the adsorption sites of $\mathrm{P}$ in the soil, and/or complex metal cations such as Fe and $\mathrm{Al}$, removing the metals from the adsorption surface and decreasing the number of available sites or decreasing the adsorption force of $\mathrm{P}$ at these sites (Guppy et al., 2005).

Table 2. Mean values of $\mathrm{Ca}, \mathrm{Mg}, \mathrm{P}, \mathrm{K}$ and TOC for the different soil management systems.

\begin{tabular}{|c|c|c|c|c|}
\hline \multirow{3}{*}{ Treatments } & $P$ & $\mathrm{Ca}$ & $\mathrm{Mg}$ & $\mathrm{K}^{+}$ \\
\hline & $\mathrm{mg} \mathrm{kg}^{-1}$ & \multicolumn{3}{|c|}{ - } \\
\hline & \multicolumn{4}{|c|}{$0.0-0.05 \mathrm{~m}$} \\
\hline 'WC & $41.6 \mathrm{Ca}^{*}$ & $0.89 \mathrm{Ca}$ & $0.77 \mathrm{Ca}$ & $0.09 \mathrm{Ba}$ \\
\hline $\mathrm{CT}$ & $78.6 \mathrm{Ba}$ & $2.6 \mathrm{Ba}$ & $1.3 \mathrm{Ba}$ & $0.58 \mathrm{Aa}$ \\
\hline LC & $151.4 \mathrm{Aa}$ & $3.6 \mathrm{Aa}$ & $1.8 \mathrm{Aa}$ & $0.68 \mathrm{Aa}$ \\
\hline \multirow[t]{2}{*}{ MC } & $151.4 \mathrm{Aa}$ & 3.7 Aa & $1.8 \mathrm{Aa}$ & $0.62 \mathrm{Aa}$ \\
\hline & \multicolumn{4}{|c|}{$0.05-0.10 \mathrm{~m}$} \\
\hline $\begin{array}{l}{ }^{*} \mathrm{WC} \\
\mathrm{CT}\end{array}$ & $\begin{array}{l}37.4 \mathrm{Ca} \\
71.5 \mathrm{Ba}\end{array}$ & $\begin{array}{c}0.97 \mathrm{Ca} \\
2.6 \mathrm{Ba}\end{array}$ & $\begin{array}{c}0.91 \mathrm{Ca} \\
1.2 \mathrm{Ba}\end{array}$ & $\begin{array}{l}0.07 \mathrm{Ba} \\
0.41 \mathrm{Ab}\end{array}$ \\
\hline LC & 132.7 Aa & $3.6 \mathrm{Aa}$ & $1.9 \mathrm{Aa}$ & $0.41 \mathrm{Ab}$ \\
\hline$M C$ & $174.2 \mathrm{Aa}$ & $3.5 \mathrm{Aa}$ & $2.0 \mathrm{Aa}$ & $0.44 \mathrm{Ab}$ \\
\hline
\end{tabular}

Same letters: means are not different according to Tukey's test $(p<0.05)$. Uppercase letters between treatments and lowercase letters between systems. 'WC - without soil cover, CT - conventional tillage, LC - level cultivation, MC - minimum cultivation.

In addition, sorption of MOS compounds may increase the negative charge at the soil surface, making difficult the $P$ adsorption and increasing its availability (Guppy et al., 2005). Similar pattern can occur with $\mathrm{Ca}$ and $\mathrm{Mg}$ cations, where higher contents of MOS raise the CTC, retaining the cations in the system with consequent decrease of losses (Souza \& Alves, 2003).

A similarity was observed in $K$ values between cultivated systems (CT, LC and MC) in the 0.0-0.10 m layer (Table 2). This pattern may be related to the high mobility of this nutrient, added to its contribution by the vegetal residues in the LC and MC, as well as by the burning performed in the CT area. In this way, as potassium fertilization was the same among treatments, these organic contributions may have contribute to change the total losses of this nutrient caused by erosion. Pavinato et al. (2009) when evaluating different management systems, also did not verify changes in $\mathrm{K}$ levels between $\mathrm{CT}$ areas and conservation systems. These authors also related this result to the superficial deposition of residues, which provides more of this nutrient through its decomposition. In the case of the CT, the ashes of the burned vegetation incorporated with the harrowing can be the source of additional $K$ in this system, since according to Silva \& Silva (2006) this nutrient is released after the vegetation burning. Considering the above, it is verified that the soil $K$ content was less affected by soil losses due to erosion in the cultivated systems, when compared to other macronutrients.

However, it should be emphasized that the data of $\mathrm{K}$ loss in the runoff water and in the sediments show higher loss of this nutrient in systems with higher soil rotation and less vegetal cover, being able to promote future economic and environmental damages in these areas. 
The results of the principal component analysis summarized the data previously discussed, where it is possible to observe a distinct separation of soil management systems according to the evaluated variables (Figure 4). In the axis 1 the isolation of the PC is observed, followed by the grouping of the positive vectors (PLW, LKS, LPS, SL2000, SL2001, KLW and LTOCS) demonstrating that the downhill plowing and harrowing lead to an exposed soil to the sun and rain action, reducing its BIT and increasing the losses of soil, TOC, P and K, which consequently reduced its fertility, when comparing to the LC and MC systems.

It can also be observed in the Figure 4 the intermediate pattern of LC in comparison to the MC and CT, indicating that the adopted erosion control practices in this treatment are contributing to the reduction of soil losses, TOC, $P$ and $K$, resulting in a higher soil fertility when compared to CT.

The clustering of the negative vectors (TOC, BIR, TCaS, TMgS and TPS) in the direction of the $\mathrm{Fl}$ axis, near to the $\mathrm{MC}$ area, indicates that this management system was the most appropriate for the studied soil and climate conditions, due to the reduction of soil losses, TOC, P and $\mathrm{K}$ by erosion, maintaining a more sustainable system, with better soil fertility.

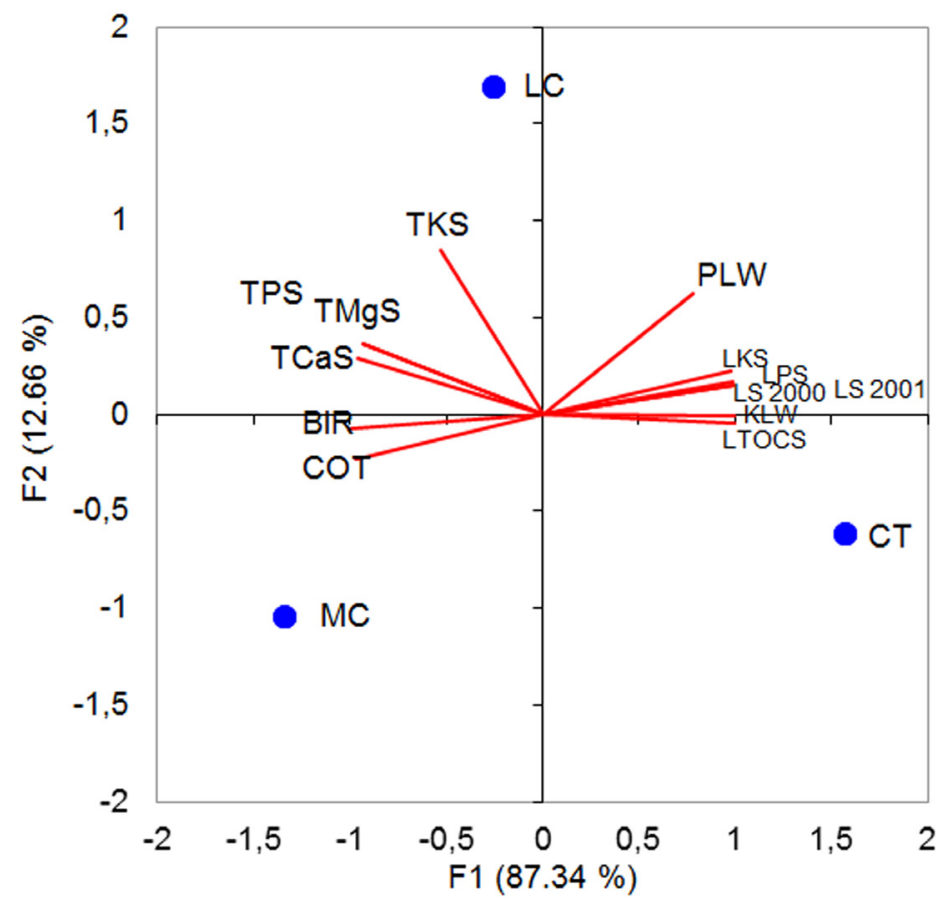

Figure 4. Principal component analysis of the evaluated characteristics, BIR (basic infiltration of water in the soil); TOC (total soil organic carbon content); SL 2000 (soil loss in the year 2000), SL 2001 (soil loss in the year 2001); KLW (loss of K by runoff water); PLW (loss of P by flood water); LPS (loss of P in sediments); LKS (loss of K in sediments); LTOCS (loss of TOC in sediments); TPS (soil P content); TCaS (Ca content in soil); TMgS (Mg content in soil) and TKS (soil K content).

\section{Conclusions}

The WC system reduces soil BIR values and provided highest losses of soil, TOC and macronutrients ( $\mathrm{P}, \mathrm{Ca}, \mathrm{Mg}$ and $\mathrm{K}$ ).

Among the cultivated systems, CT showed a degrading system, with losses of soil TOC, $P$ and $K$ by erosion, contributing to the reduction of TOC, $\mathrm{P}, \mathrm{Ca}, \mathrm{Mg}$ and $\mathrm{BIR}$ levels in the soil. In contrast, in the soil and climatic conditions of this study, the MC is the most indicated, since it contributes to the reduction of losses of TOC, $\mathrm{P}$ and $\mathrm{K}$ by erosion, besides increasing TOC, BIR, $\mathrm{P}$, $\mathrm{K}$, Ca and Mg of the soil.

The adopted practices to control erosion in $L C$ reduced the soil, TOC, $P$ and $K$ losses when compared to $\mathrm{CT}$, increasing the BIR values. As a consequence, the LC resulted in similar contents of TOC, P, Ca and Mg than MC, demonstrating that simple practices to control erosion can improve the soil chemical and physical conditions. 


\section{References}

Amaral Sobrinho, N.M.B., Mazur, N. 2005. Soil preparation and nutrient losses by erosion in the culture of cucumber. Scientia Agricola 62: 572577.

Bezerra, S.A., Cantalice, J.R.B. 2006. Erosão entre sulcos em diferentes condições de cobertura do solo, sob cultivo da cana-de-açúcar. Revista Brasileira de Ciência do Solo 30: 565-573.

Cunha, J.L.X.L., Silva, C.A., Coelho, M.E.H., Fontes, L.O., Silva, M.G.O., Silva, I.N. 2011 . Velocidade de infiltração da água em um latossolo amarelo submetido ao sistema de cultivo mínimo. Agropecuária Científica no Semi-Árido 07: 30-35.

Donagema, G.K., Campos, D.V.B. de, Calderano, S.B., Teixeira, W.G.; Viana, J.H.M. (Org.).2011. Manual de métodos de análise de solos. 2.ed. rev. Rio de Janeiro: Embrapa Solos, 230p. (Embrapa Solos. Documentos, 132).

Fontes, R.L.P., Gomes, G.R., Bertolino, A.V.F.A., Bertolino, L.C. 2013. Regeneração de um solo sob agricultura orgânica em diferentes manejos: estação experimental da Pesagro, Paty do alferes - Rio de janeiro. Revista Tamoios 09: 28-41.

Garcia, R.A., Crusciol, C.A.C., Calonego, J.C., Rosolem, C.A. 2008. Potassium cycling in a cornbrachiaria cropping system. Europa Jounal Agronomy 28: 579-585.

Guppy, C.N., Menzies, N.W., Moody, P.W., Blamey, F.P.C. 2005. Competitive sorption reactions between phosphorus and organic matter in soil: A review. Australian Journal Soil Reshearch 43: 189-202.

Guareschi, R. F.; Pereira, M. G.; Perin, A. 2012. Deposição de resíduos vegetais, matéria orgânica leve, estoques de carbono e nitrogênio e fósforo remanescente sob diferentes sistemas de manejo no cerrado goiano. Revista Brasileira de Ciência do Solo, 36: 909-920.

Leite, M.H.S., Couto, E.G., Amorim, R.S.S., Costa, E.L., Maraschin, L. 2009. Perdas de solo e nutrientes num latossolo vermelho-amarelo ácrico típico, com diferentes sistemas de preparo e sob chuva natural. Revista Brasileira de Ciência do Solo 33: 689-699.

Panachuki, E., Bertol, I., Sobrinho, T.A., Oliveira, P.T.S., Rodrigues, D.B.B. 2011. Perdas de solo e de água e infiltração de água em latossolo vermelho sob sistemas de manejo. Revista Brasileira de Ciência do Solo 35: 1777-1785.

Pavinato, P.S., Merlin, A., Rosolem, C.A. 2009. Disponibilidade de cátions no solo alterada pelo sistema de manejo. Revista Brasileira de Ciência do Solo 33: 1031-1040.
Pereira, L.S., Rodrigues, A.M. 2013. Sistemas de Manejo de Cultivo Mínimo e Convencional: Análise Temporal da Dinâmica Hidrológica do Solo e da Variação Produtiva em Ambiente Serrano. Revista Brasileira de Geografia Física 06: 1658-1672.

Pinheiro, E.F.M., Pereira, M.G., Anjos, L.H.C., Palmieri, F., Souza, R.C. 2003. Matéria orgânica em latossolo vermelho submetido a diferentes sistemas de manejo e cobertura do solo. Revista brasileira de Agrociência 09: 53-56.

Pinheiro, E.F.M., Pereira, M.G., Anjos, L.H.C., Machado, P.L.O.A. 2004. Fracionamento densimétrico da matéria orgânica do solo sob diferentes sistemas de manejo e cobertura vegetal em Paty do alferes (RJ). Revista Brasileira de Ciência do Solo 28: 731-737.

Portela, J.C., Cogo, N.P., Bagatini, T., Chagas, J.P., Portz, G. 2010. Restauração da estrutura do solo por sequências culturais implantadas em semeadura direta, e sua relação com a erosão hídrica em distintas condições físicas de superfície. Revista Brasileira de Ciência do Solo 34: 1353-1364.

Santos, H. G. dos; Jacomine, P. K. T.; Anjos, L. H. C. dos; Oliveira, V. A. de; Lumbreras, J. F.; Coelho, M. R.; Almeida, J. A. de; Cunha, T. J. F.; Oliveira, J. B. de. 2013.Sistema brasileiro de classificação de solos. 3. ed. rev. e ampl. Brasília, DF: Embrapa, $353 \mathrm{p}$.

Santos, F.S., Amaral Sobrinho, N.M.B., Mazur, N. 2002. Influência de diferentes manejos agrícolas na distribuição de metais pesados no solo e em plantas de tomate. Revista Brasileira de Ciência do Solo 26: 535-543.

Silva, A.S., C. Silva. 2006. Prática de queimadas e as implicações sociais e ambientais na cidade de Araguaina-TO. Revista Caminhos de Geografia 18: 8-16.

Souza, Z.M., Alves, M.C. 2003. Propriedades químicas de um Latossolo Vermelho distroférrico de cerrado sob diferentes usos e manejos. Revista Brasileira de Ciência do Solo 27: 133-139.

Thomazini, A., Azevedo, H.C.A., Mendonça, E.S., 2012. Perdas de solo, água e nutrientes em sistemas conservacionistas e convencionais de café no sul do estado do Espírito Santo. Revista Brasileira de Agroecologia 07: 150-159.

Trevisan, L.R., Lana, R.M.Q., Zanão Junior, L.A., Guimarães, E.C., Lacerda, Z.C,. 2008. Variabilidade vertical de ph, bases e enxofre em latossolo vermelho cultivado sob sistema plantio direto e cultivo mínimo. Horizonte Científico 01: 1-11. 
Núñez, J.E.V., Amaral Sobrinho, N.M.B., Mazur, N. 2006 a. Conseqüências de diferentes sistemas de preparo do solo sobre a contaminação do solo, sedimentos e água por metais pesados. Edafologia 13: 73-85.

Núñez, J.E.V., Amaral Sobrinho, N.M.B., Mazur, N. 2006 b. Conseqüências do sistema de preparo do solo no acúmulo e perda de fósforo e bases trocáveis por erosão. Edafologia 13: 55-57.

Tartari, D.T., Nunes, M.C.M., Santos, C.A., Faria Junior, C.A., Serafim, M.E. 2012. Perda de solo e água por erosão hídrica em Argissolo sob diferentes densidades de cobertura vegetal. Revista Brasileira de Agroecologia 07: 85-93.

Valadares, R.V., Duarte, R.F., Menezes, J.B.C., Fernandes, L.A., Santos, R.A., Sampaio, L.D., Mota, T.C., Almeida, R.M. 2012. Fertilidade do solo e produtividade de milho em sistemas de adubação verde no norte de minas gerais. Planta Daninha 30: 505-516. 